\title{
FOXM1 and polo-like kinase 1 are co-ordinately overexpressed in patients with gastric adenocarcinomas
}

\author{
M. Dibb ${ }^{1,2}$, N. Han ${ }^{1}$, J. Choudhury ${ }^{3}$, S. Hayes ${ }^{2,3}$, H. Valentine ${ }^{4}$, C. West ${ }^{4}$, AD Sharrocks ${ }^{1}$ and Yeng S. Ang ${ }^{2,5^{*}}$
}

\begin{abstract}
Background: Gastric cancers present late in life with advanced disease and carry a poor prognosis. Polo-like Kinase 1 (PLK1) is a mitotic kinase with regulatory functions during G2/M and mitosis in the cell cycle. In mammalian cells, there is an intricate co-regulatory relationship between PLK1 and the forkhead transcription factor FOXM1. It has been demonstrated that individually either PLK1 or FOXM1 expression predicts poorer survival. However, the co-expression of both of these markers in gastric adenocarcinomas has not been reported previously.
\end{abstract}

Methods: We aimed to assess the expression of PLK1 and FOXM1 in Gastric adenocarcinomas in a Western Population, to examine whether there is a relationship of PLK1 to FOXM1 in cancer samples. We assess both the protein and mRNA expression in this patient population by Tissue Microarray immunohistochemistry and RT-PCR.

Results: Immunohistochemistry was performed on biopsy samples from 79 patients with gastric cancer. Paired normal controls were available in 47 patients. FOXM1 expression was significantly associated with gastric adenocarcinoma ( $p=0.001)$. PLK1 and FOXM1 co-expression was demonstrated in 6/8 (75 \%) tumours when analysed by RT-PCR. FOXM1 is overexpressed in a large proportion of gastric carcinomas at the protein level and FOXM1 and PLK1 are concomitantly overexpressed at the mRNA level in this cancer type.

Conclusions: This study has demonstrated that FOXM1 and its target gene PLK1 are coordinately overexpressed in a proportion of gastric adenocarcinomas. This suggests that chemotherapeutic treatments that target this pathway may be of clinical utility.

Keywords: Gastric adenocarcinoma, FOXM1 (Forkhead Protein M1), PLK1 (Polo-like Kinase 1)

\section{Background}

Gastric adenocarcinoma remains the second commonest cause of cancer death on a worldwide basis. In the West, the incidence has been steadily declining over the past few decades [1, 2]. However, in the United Kingdom gastric cancer remains the sixth commonest cause of cancer death [3]. This is mainly due to late presentation of the disease and thus limits treatment options. The 5 -year survival rate is good if the disease is diagnosed at an early stage and large scale population screening by upper gastrointestinal endoscopy has increased the rates

\footnotetext{
*Correspondence: yeng.ang@srft.nhs.uk

${ }^{2}$ Faculty of Medical and Human Sciences, University of Manchester,

Oxford Road, Manchester, UK

Full list of author information is available at the end of the article
}

of early detection and subsequent prognosis in Japanese populations $[4,5]$. However, the incidence of gastric adenocarcinoma is much lower in the West and large scale population screening is not cost effective. Consequently, gastric adenocarcinomas are usually diagnosed at an advanced stage and typical 5-year survival is less than $15 \%$. Traditional cytotoxic chemotherapy regimens are largely ineffective in halting the disease [6-8]. Even when surgery is indicated, neoadjuvant chemotherapy improves 5-year survival rates modestly from 20 to $36 \%$ [9]. Hence novel treatments and targets for drug therapies are urgently needed to improve outcomes further.

FOXM1 is a member of the forkhead transcription factor family, which plays an important role in controlling the cell cycle $[10,11]$. Specifically, FOXM1 controls 
mitotic entry through the periodic upregulation of a group of genes that are maximally expressed as cells progress through late $\mathrm{G} 2$ and into $\mathrm{M}$ phase [12]. Two of its target genes are CCNB1 and PLK1, and these form part of a kinase-driven positive feedback loop that leads to the phosphorylation of FOXM1 and potentiation of its activity $[13,14]$. Hence, there is an intricate inter-regulatory relationship between FOXM1 and PLK1 that creates a cellcycle control switch. This important link between FOXM1 and cellcycle control suggests that it is likely to contribute to the aberrant cell proliferation associated with malignancy. In clinical settings, FOXM1 has been shown to be upregulated in a range of different tumour types [11]. More recently, FOXM1 was shown to be overexpressed and of potential prognostic significance in oesophageal adenocarcinomas and squamous carcinomas $[15,16]$. In the same fashion, the FOXM1 target gene PLK1 has also been shown to be overexpressed in a wide range of tumours [17], including oesophageal adeno- and squamous carcinomas $[15,18,19]$. Furthermore, novel molecular functions for FOXM1 have been identified in cancer cells beyond simply the acceleration of G2-M phase progression $[11,20]$. This is exemplified by its ability to promote the nuclear translocation of $\beta$-catenin in gliomas, and consequently it can activate a whole programme of Wnt target genes [21]. Taken together, these findings indicate that FOXM1 and PLK1 are likely central regulators in carcinogenesis and are therefore potential therapeutic targets.

In the current study, we investigate the expression of FOXM1 and PLK1 in gastric adenocarcinomas with particular emphasis on examining whether there is evidence that FOXM1and PLK1 are co-ordinately expressed. We aimed to show that there is a relationship of PLK1 to FOXM1 in cancer samples. Such co-regulation in cancer samples has not previously been investigated; as studies have been limited to studying either FOXM1 or PLK1 expression in these tumours [22,23]. We previously demonstrated co-upregulation of these proteins in oesophageal adenocarcinomas [15]. We now show that there is also coordinate overexpression of FOXM1 and PLK1 in gastric adenocarcinomas, thereby providing the potential for feedback potentiation of FOXM1 activity. PLK1 inhibitors are currently being developed for cancer therapy $[17,24]$ and it is likely that cells demonstrating coordinated up regulation of FOXM1 and PLK1 expression will be particularly susceptible to such treatment.

\section{Methods}

\section{Tissue collection}

The Wrightington, Wigan and Leigh NHS Local Research and Ethics Committee initially granted ethical approval in 2007. Tissue was obtained a total of 79 gastric carcinomas and 47 healthy controls have been directly recruited. Patients who had received neo-adjuvant chemotherapy were excluded. Paraffin Blocks were also used to construct slides for immunohistochemistry.

Demographic Information, including age at diagnosis, sex, co-morbidity and survival was collected on all patients. Tumour grade and stage were documented using the TNM and AJCC criteria. Biopsy samples were collected during endoscopy from the tumour and where possible from macroscopically normal adjacent tissue at least $5 \mathrm{~cm}$ away from macroscopic evidence of tumour. Endoscopic biopsy samples were then either snap-frozen in liquid nitrogen or collected in RNAlater (Qiagen Laboratories)@. They were then archived at $-80^{\circ} \mathrm{C}$ until needed. A small number of surgical samples were also taken. These were dissected from the tumour and adjacent normal tissue by a histopathologist immediately after removal from the patient. Surgical samples were frozen in liquid nitrogen and then stored at $-80^{\circ} \mathrm{C}$. Samples were used for RNA extraction and protein analysis.

\section{Immunohistochemistry}

Tissue microarray (TMA) blocks were constructed from surgical tumour block resections and biopsies as described previously in our laboratory [15]. Three arrays were constructed for each case and stained with mouse anti-PLK1 antibody (Zymed 37-7100) or Rabbit polyclonal anti-FOXM1 antibody (SC-500, Santa Cruz, FoxM1 K19 antibody) as previously described [15]. The slides were scored jointly by JC, MD and $\mathrm{SH}$ using a Nikon Eclipse 50 Microscope (blinded). The slides were also scanned using a MIRAX 3Dhistotech system for reference and archive purposes. The scores were calculated by subjectively assessing nuclear intensity on a score of zero to three. The percentage of cells showing nuclear staining was documented to the nearest five percent. An overall score was obtained by multiplying the intensity by the percentage.

\section{RNA isolation and RT-PCR analysis}

RNA was extracted, it's integrity determined and subsequent real-time RT-PCR performed for PLK1 and FOXM1 RNA using SYBR Green as described previously [15]. RNA samples from all human tissue specimens were validated using an Agilent 2100 bioanalyser with a RNA 6000 Nano assay lab chip kit. For relative comparison of mRNA levels from tissue specimens, data were further normalised to the level of each gene in a stock standard concentration of RNA isolated from Het1a cells. The cell lines were cultured and lysed as described previously [15].

RT-PCR primers were designed using the internet programs Primer 3 (http://frodo-wi.mit.edu/primer3/input. 
htm) and NCBI primer blast (http://www.ncbi.nlm.nih. gov/tools/primer-blast/). All primers were designed to cross an intron-extron junction sequence to minimize amplifying genomic DNA contamination. Ribosomal $18 \mathrm{~S}$ RNA, $\beta$-actin, and GAPDH were assessed as housekeeping genes for the normalization of the clinical biopsy samples and samples were ultimately normalized to $18 \mathrm{~S}$ RNA.

\section{Statistics}

SPSS $16.0\left(\mathrm{IBM}^{\circledR}\right.$, New York, USA) was used for statistical analysis. The paired $\mathrm{T}$ test was used to compare continuous variables. Chi-Square, Mann-Whitney U (nominal variables with two values) and Kruskal-Wallis (nominal variables with multiple values) were used to compare discrete variables. Kaplan-Meier analysis was used to calculate survival curves by univariate and multivariate analysis respectively. Significance was accepted to be present with a p value of less than 0.05 .

\section{Results}

\section{FOXM1 protein expression}

Samples were obtained from 79 patients with gastric adenocarcinomas in a large general hospital with an established cancer surgical service (Table 1). 47 patients had paired normal gastric tissue obtained $>5 \mathrm{~cm}$ from the edge of the tumour. Tissue microarrays (TMAs) consisting of biopsies of clinical endoscopic and surgical resection specimens were constructed. The expression of FOXM1 was then probed using the FOXM1 K19 antibody.

First, to confirm the validity of the FOXM1 antibody and assess protein expression in tumour samples we performed western blot analysis of FOXM1 expression in corresponding tissue types from 3 types of gastrectomy specimens: normal tissue $(\mathrm{N})$, high grade dysplasia (D) and tumour $(\mathrm{T})$. This is suggestive of enhanced levels of FOXM1 protein in both dysplastic tissue and gastric adenocarcinomas (Fig. 1, lanes 3 and 6). Next we analysed FOXM1 protein expression using the TMAs. FOXM1 was shown to cause predominant nuclear staining in gastric adenocarcinomas, although some cytoplasmic staining was seen (Fig. 2a). Staining of varying degrees was seen across the cores. For the negative controls sections we have pre-incubated the antibody with its peptide and there was no staining, hence we are confident of its specificity. As it is a commercially available antibody, we use a standardised positive control and hence confident of the sensitivity. Gastric adenocarcinoma samples had a higher IHC score than paired normal tissues (Fig. 2b) (Paired T test $\mathrm{p}=0.001$ ) IHC. Moderate to high FOXM1 expression was significantly associated with gastric adenocarcinoma compared to non-cancer
Table 1 Demographics, clinical staging, treatments and FOXM1 protein expression in gastric tissue

\begin{tabular}{|c|c|c|}
\hline & Normal gastric tissue & $\begin{array}{l}\text { Gastric adenocarci- } \\
\text { noma }\end{array}$ \\
\hline Number of cases & 47 & 79 \\
\hline Male & $30(64 \%)$ & $46(58 \%)(p=0.87)$ \\
\hline Age & $69 \pm 9$ & $70 \pm 11(p=0.94)$ \\
\hline \multicolumn{3}{|c|}{ Pathological differentiation } \\
\hline Poor & & $40(51)$ \\
\hline Moderate & & $28(35)$ \\
\hline Well & & $9(11)$ \\
\hline Missing & & $2(3)$ \\
\hline \multicolumn{3}{|l|}{ Depth of invasion } \\
\hline $\mathrm{T} 1$ & & $8(10)$ \\
\hline $\mathrm{T} 2$ & & $22(28)$ \\
\hline T3 & & $42(53)$ \\
\hline T4 & & $5(6)$ \\
\hline Missing & & $1(1)$ \\
\hline \multicolumn{3}{|l|}{ Metastatic disease } \\
\hline Local (N) & & $53(67)$ \\
\hline Distant (M) & & $4(5)$ \\
\hline \multicolumn{3}{|l|}{ AJCC 2010 stage } \\
\hline 1 & & $15(19)$ \\
\hline 2 & & $22(28)$ \\
\hline 3 & & $31(39)$ \\
\hline 4 & & $9(11)$ \\
\hline Missing & & $1(1)$ \\
\hline \multicolumn{3}{|l|}{ Treatment } \\
\hline Surgery & & $65(82)$ \\
\hline $\begin{array}{l}\text { Surgery and chemo- } \\
\text { therapy }\end{array}$ & & $5(6)$ \\
\hline Chemotherapy & & $6(8)$ \\
\hline Palliative care & & $2(3)$ \\
\hline Missing & & $1(1)$ \\
\hline \multicolumn{3}{|l|}{ FOXM1 mRNA expression } \\
\hline Positive expression & $26(55)$ & $56(71)(p=0.001)$ \\
\hline $\begin{array}{l}\text { High positive expres- } \\
\text { sion }\end{array}$ & $1(2)$ & $23(29)(p=0.001)$ \\
\hline
\end{tabular}

The number of cases is illustrated, percentages are in brackets. The number of patients with missing data is indicated. Positive expression was taken as an immunohistochemistry score of $>90$ and High positive expression was taken as an immunohistochemistry score $>150$. $\mathrm{P}$ values calculated by $\mathrm{Chi}^{2}$ test are indicated

tissue (Mann-Whitney U p = 0.001) (Fig. 2c). FOXM1 positive expression was seen in up to $55 \%$ of the paired normal gastric tissues but of these $65 \%$ were low positive expression. There were no significant differences between FOXM1 expression and tumour depth, nodal metastasis, distant metastasis or AJCC stage (Fig. 2d). FOXM1 expression did not have a correlation between survival or recurrence in gastric adenocarcinomas (data not shown). 


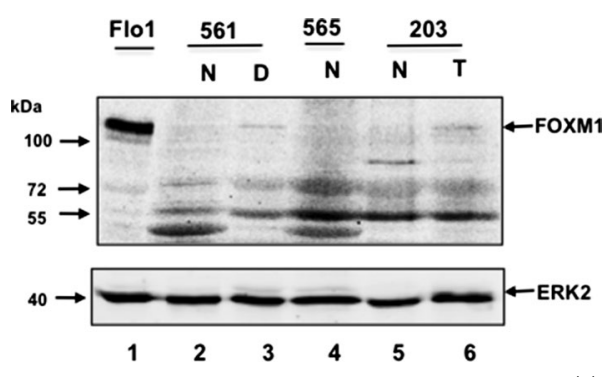

Fig. 1 FOXM1 protein expression in gastric tissue. Western blots of FOXM1 protein expression in the indicated tissue type are shown. Molecular weights are in kDa. Results of normal gastric mucosa (N) and Tumour (T) or high grade dysplasia (D) in specimens 571,565,187 from three gastrectomies are shown. Flo1 cell lysate is shown in the left lane. ERK2 was used as a loading control

\section{PLK1 and FOXM1 mRNA expression in Gastric Adenocarcinoma}

Having established up-regulation of FOXM1 protein expression in gastric cancers, we next wanted to test whether we could detect co-upregulation of PLK1. However we were unable to find a suitable antibody for IHC so instead we turned to RT-PCR analysis. We quantified FOXM1 and PLK1 mRNA expression using real-time RT-PCR and normalised mRNA levels to $18 \mathrm{~S}$ ribosomal RNA. Samples from 22 patients were included in the study with patients being divided into tissue groups. The groups included tissue from macroscopically normal gastric epithelium from healthy controls $(n=13)$ and gastric adenocarcinoma patients $(n=8)$. The clinical details are indicated in Table 2.

The expression levels of both PLK1 and FOXM1 mRNA are higher in gastric adenocarcinoma tissue compared to gastric tissue from healthy controls (Fig. 3a, b). Median expression levels are increased ninefold for both PLK1 (paired $\mathrm{T}$ test $\mathrm{p}=0.007$ ) and FOXM1 (paired $\mathrm{T}$ test $\mathrm{p}=0.001$ ) (Fig. 3c). 5/8 (63 \%) tumour samples demonstrated high levels of PLK1 and FOXM1. Importantly there was a strong correlation between FOXM1 levels with PLK1 expression levels across all the samples tested $\left(\mathrm{R}^{2}=0.608\right.$; Fig. $\left.3 \mathrm{~d}\right)$ suggesting a direct co-regulatory relationship. No normal samples expressed high levels of PLK1 and FOXM1. Given the small sample size it is not appropriate to analyse mRNA expression levels for clinical correlations.

\section{Discussion}

In this study we have demonstrated that FOXM1 protein, and PLK1 and FOXM1 mRNA levels are all markers of gastric adenocarcinoma when compared to normal gastric tissue. Importantly, we provide evidence for coupregulation of FOXM1 and PLK1 expression in these cancers as predicted from their co-regulatory association. Previous groups have demonstrated FOXM1 overexpression in cancer $[15,25,26]$. FOXM1 has previously been shown to be overexpressed in $88 \%$ of gastric adenocarcinomas in a cohort of Chinese patients [26]. PLK1 has separately been reported to be overexpressed in gastric cancer patients [22, 27]. Our results are consistent with this and confirm the overexpression of both FOXM1 protein and mRNA in gastric cancer. We did not find any associations with clinical characteristics or prognosis within our immunohistochemistry analysis. Li et al. [25] demonstrated a highly significant association between immunohistochemical expression of FOXM1 and prognosis. Both studies had similar number of therapeutic characteristics. The reason for the differences in prognostic association is unclear. It is possible that there was a difference in the numbers of proximal and distal gastric cancers between the two groups or other factors between our British population that differ from the American population in their study. It can be surmised there was a general consistency between both our protein and RNA results and these overexpression seen by other groups in gastric cancer.

It is perhaps of interest to assess whether PLK1 or FOXM1 have utility aiding with prognostic assessment and identifying populations that might respond to targeted therapies. The data from our Real time RT-PCR analysis of PLK1 and FOXM1 in cancer samples did not show a statistically significant survival benefit in either the surgical or non-surgical patient group. This may be as a result of the heterogenicity of the small gastric cancer population in the samples we collected. Clinically homogenous populations are more useful for assessing survival benefit. American and UK groups have previously used microarray data from surgical patients with oesophageal cancer to demonstrate two and four gene signatures that have prognostic value [23, 28]. PLK1 was found to be a potential prognostic marker by one of these studies although this was not further validated [23]. Validation of microarray findings is important because there can be poor correlations between qRTPCR and normalized microarray data for up to $16 \%$ of genes [29].

PLK1 inhibitors are in active development as oncology treatments [30]. It is possible that PLK1 inhibition will be of clinical utility in treating gastric cancer patients. Initial phase II trials including those utilising BI 2536 have been disappointing with no patients with advanced disease having a complete or partial response [31]. Drug limiting effects including neutropenia, thrombocytopenia and anaemia were observed frequently. It is therefore unsurprising that the major limiting side effects relate to impairment of rapidly proliferating tissues given PLK1's 


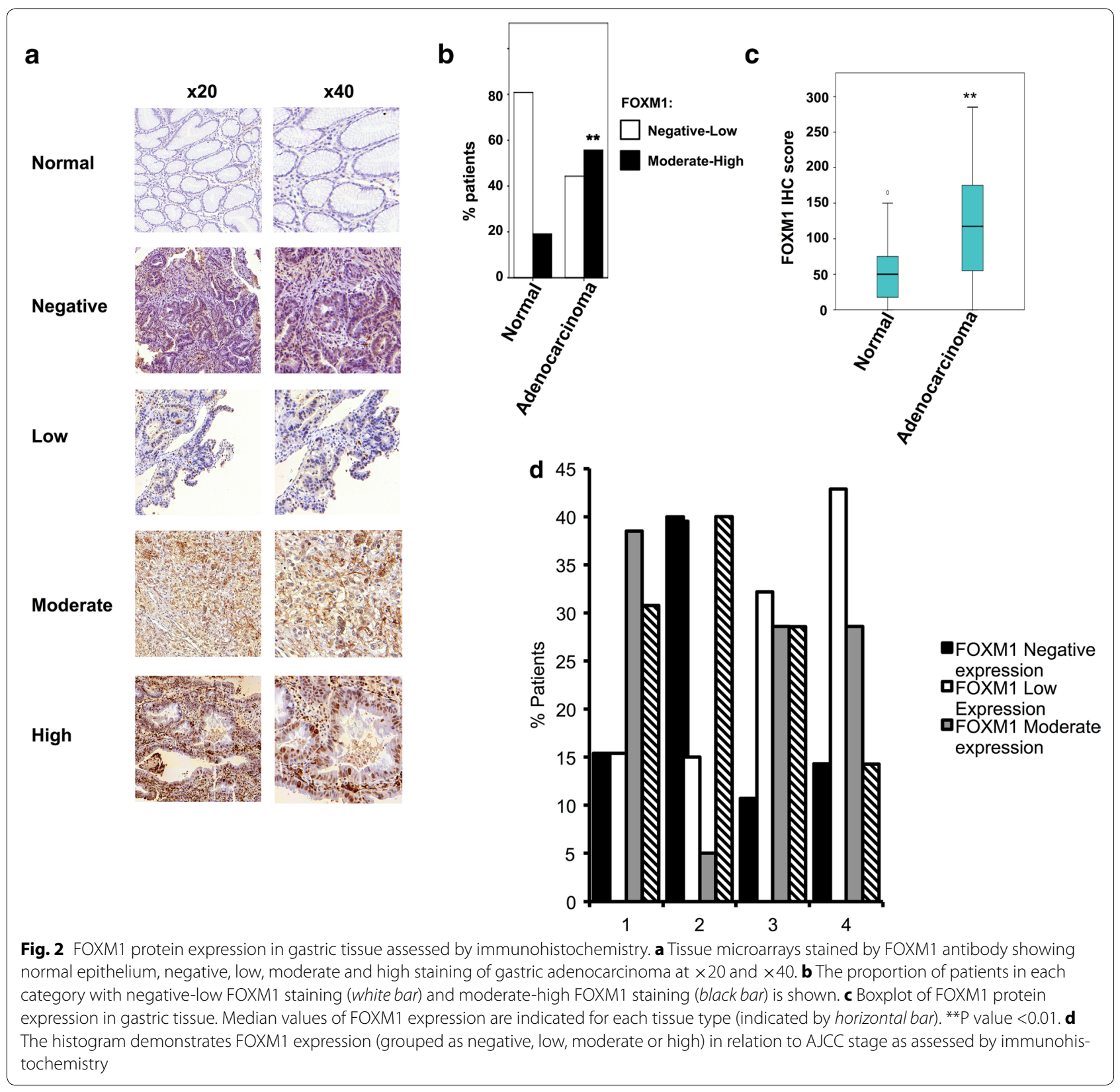

major role in regulating the cell cycle. Whilst patients did not gain a significant clinical response to BI2536 treatment it is worth noting that some tumour types did enter a period of stable non-progressive disease, particularly ovarian cancer patients [31]. A recent phase I clinical trial which used another PLK1 inhibitor GSK461364, found that stable disease was achieved for greater that 4 months in $6 / 40$ patients [32]. Interestingly all of the responders to treatment had significantly higher PLK1 and KI67 levels when assessed by immunohistochemistry. This may suggest PLK1 inhibition may be of most use in the subset of patients with overexpression of FOXM1 and it's target genes.

\section{Conclusion}

It is clear that both PLK1 and FOXM1 are tightly regulated to prevent inappropriate proliferation, and both have widespread interactions throughout the cell cycle. Carcinogenesis is a dynamic process with changes in the genome, transcriptome, intra/extracellular signalling throughout the tumour, as well as alterations to the surrounding vascular and stromal tissue. Whilst our results 
Table 2 Demographics, clinical staging, treatments, PLK1 mRNA and FOXM1 mRNA expression of the patients in each tissue group

\begin{tabular}{|c|c|c|}
\hline & Gastric normal & Gastric adenocarcinoma \\
\hline Number of cases & 13 & 8 (1HGD) \\
\hline Male & $4(31)$ & $7(88)(p=0.02)$ \\
\hline Age & $72 \pm 3$ & $70 \pm 4(p=0.45)$ \\
\hline \multicolumn{3}{|l|}{ Smoking } \\
\hline Never & $1(8)$ & $1(11)(p=0.45)$ \\
\hline Ex-smoker & $1(8)$ & $2(22)(p=0.98)$ \\
\hline Current & $5(38)$ & $6(67)(p=0.09)$ \\
\hline Missing & $6(46)$ & 0 \\
\hline \multicolumn{3}{|l|}{ Pathological differentiation } \\
\hline Poor & & $6(75)$ \\
\hline Moderate & & 0 \\
\hline Well & & 0 \\
\hline Missing & & $2(25)$ \\
\hline \multicolumn{3}{|l|}{ Depth of invasion } \\
\hline $\mathrm{T} 1$ & & $1(13)$ \\
\hline $\mathrm{T} 2$ & & $2(25)$ \\
\hline T3 & & $3(50)$ \\
\hline T4 & & 0 \\
\hline Missing & & $1(13)$ \\
\hline \multicolumn{3}{|l|}{ Metastatic disease } \\
\hline Local (N) & & $3(37.5)$ \\
\hline Distant (M) & & $0(0)$ \\
\hline \multicolumn{3}{|l|}{ AJCC 2010 Stage } \\
\hline 1 & & $2(25)$ \\
\hline 2 & & $3(36)$ \\
\hline 3 & & $2(25)$ \\
\hline 4 & & 0 \\
\hline Missing & & $1(13)$ \\
\hline \multicolumn{3}{|l|}{ Treatment } \\
\hline Surgery & & $6(75)$ \\
\hline Surgery and chemotherapy & & $1(13)$ \\
\hline Chemotherapy & & 0 \\
\hline Chemo-radiotherapy & & 0 \\
\hline EMR & & 0 \\
\hline Palliative care & & $1(13)$ \\
\hline Missing & & 0 \\
\hline \multicolumn{3}{|l|}{ PLK1 mRNA expression } \\
\hline mRNA level $\times 10$ & 2.1 & 18.8 \\
\hline Positive expression & $2(15)$ & $5(63)(p=0.056)$ \\
\hline \multicolumn{3}{|l|}{ FOXM1 mRNA expression } \\
\hline mRNA level $\times 10$ & 1.2 & 9.2 \\
\hline Positive expression & $0(0)$ & $6(75)(p=0.001)$ \\
\hline
\end{tabular}

The number of cases is shown in each category, percentages are in brackets. mRNA levels are mean expression levels and standard deviation relative to $18 \mathrm{~S}$ ribosomal RNA and standards derived from HET1a cell lines. The number of patients with clinical data missing is indicated. Positive expression is defined as an expression level equal or higher to the mean of the normal sample plus two standard deviations about the mean for the indicated gene. P values calculated by Chi ${ }^{2}$ test are indicated $H G D$ high grade dysplasia, EMR endoscopic mucosal resection 
a

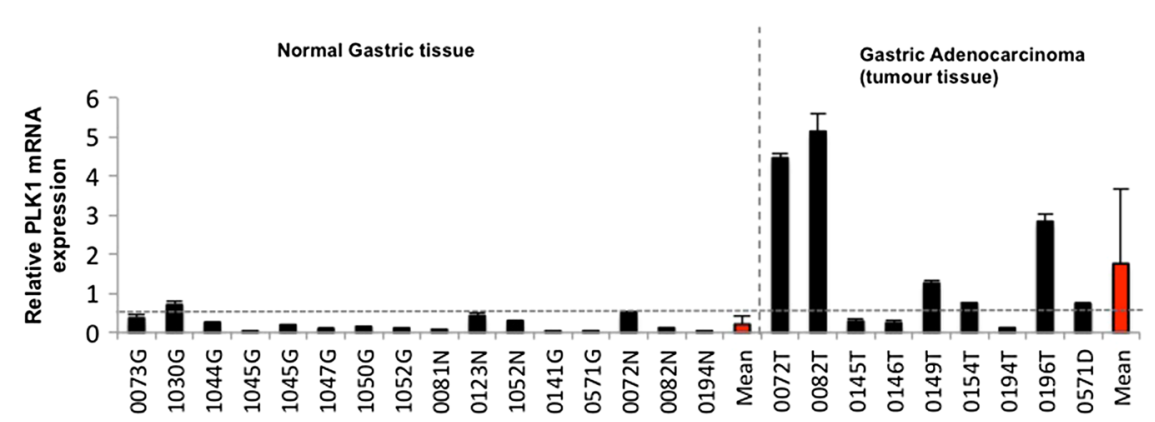

b

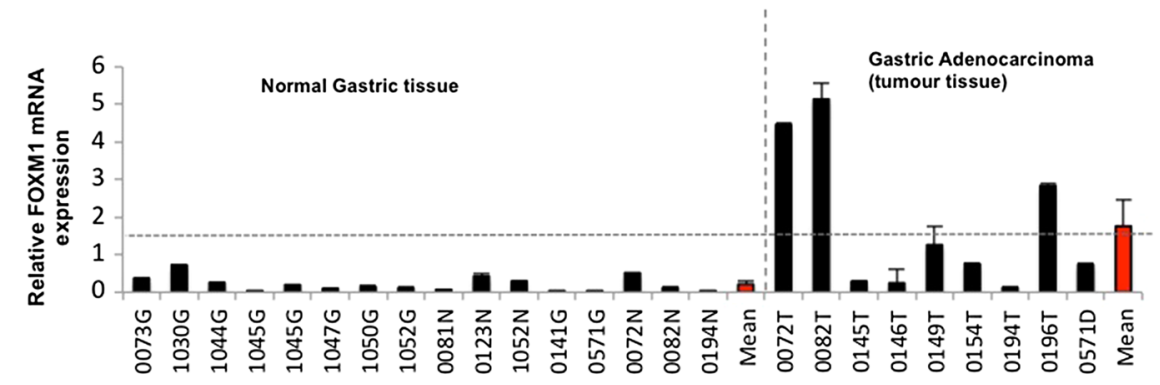

C
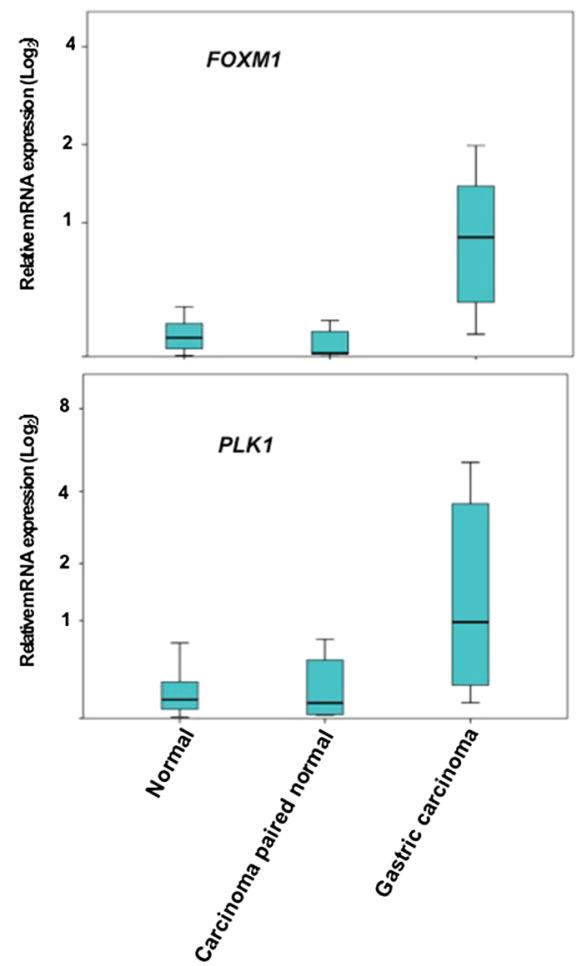

d

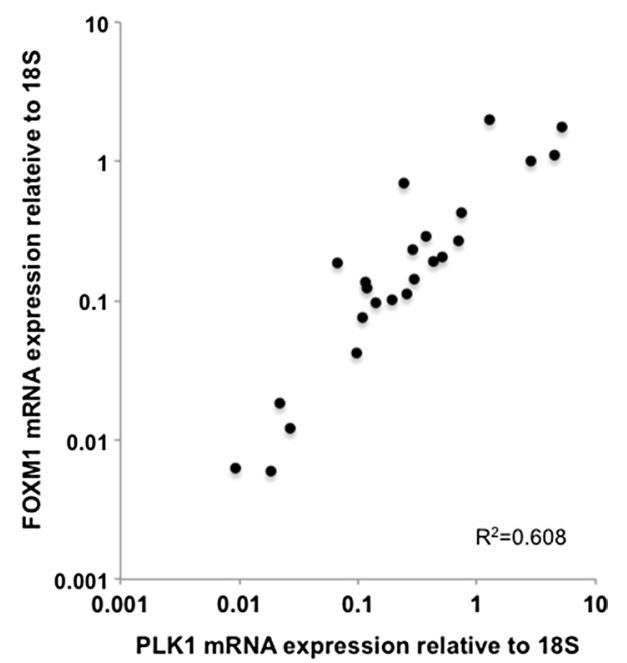

Fig. $3 P L K 1$ and FOXM1 expression in normal gastric tissue and gastric adenocarincoma. a Histograms of the mRNA levels of PLK1 and FOXM1 relative to 185 mRNA in gastric tissue. Data was standardized relative to the gene expression in stock mRNA samples prepared from the Het1a cell line. The average relative mRNA level and standard deviations derived from two readings from one sample are shown. The individual tissue specimens are numbers and samples are grouped by tissue sub-types. The mean gene expression in each category is shown in red. Positive expression (calculated as two standard deviations above the mean of the value in normal samples) is illustrated by the horizontal dotted line. b Box plots of PLK1 and FOXM1 mRNA expression. The box plot demonstrates the interquartile range. Median expression values are indicated by the horizontal lines. $\mathbf{c}$ Scatterplot indicating the expression of FOXM1 relative to $P L K 1$ mRNA expression. $R^{2}$ value is indicated 
suggest that both PLK1 and FOXM1 are implicated in carcinogenesis in gastric adenocarcinoma, blockade of one regulatory pathway is unlikely to halt cancer progression and induce widespread apoptosis in vivo. Increasingly more recent cancer therapies often involve blockade of multiple pathways using a combination of therapeutic agents and it may be that targeting FOXM1 pathways will prove a useful treatment adjunct.

Work is already being undertaken in our laboratory to identify new FOXM1 target genes using ChIP-seq technologies. Future work will focus on using gene expression array data to assess alternative FOXM1 targets and novel FOXM1 interactions in gastric cancer. FOXM1's multiple potential roles in carcinogenesis suggest that the development of chemotherapy that targets the FOXM1 regulatory network may have clinical utility.

\section{Authors' contributions}

MD contributed to the study design, conducted the majority of the experiments and helped with manuscript preparation. JC, MD and SH assisted with tissue sampling and IHC analysis. HV and CW assisted with the TMA experiments. NH performed the bioinformatics analysis. ADS contributed to experimental design, supervision of laboratory experiments, manuscript preparation and coordination of the project. YA provided clinical training, contributed to study design, coordination and data interpretation and wrote the manuscript. All authors read and approved the final manuscript.

\section{Author details \\ ${ }^{1}$ Faculty of Life Sciences, University of Manchester, Michael Smith Building, Oxford Road, Manchester M13 9PT, UK. ${ }^{2}$ Faculty of Medical and Human Sci- ences, University of Manchester, Oxford Road, Manchester, UK. ${ }^{3}$ Department of Histopathology, Salford Royal Foundation Trust, Stott Lane, Salford M6 8HD UK. ${ }^{4}$ School of Cancer and Enabling Sciences, Christie Hospital, Manchester Academic Health Science Centre, The University of Manchester, Manchester, UK. ${ }^{5} \mathrm{Gl}$ Science Centre, Salford Royal NHS FT, University of Manchester, Stott Lane, Salford M6 8HD, UK.}

\section{Acknowledgements}

We thank Karren Palmer, and Zongling Ji for excellent advice and technical assistance; members of our laboratory for comments on the manuscript and discussion. This work was supported by grants from Research and Development (ABJ0026) and the Cancer Therapy and Research.

Fund from the WWL NHS Foundation Trust and from the department of Gastroenterology to RK and YSA, the UK NIHR/UKCRN (UK National Institute of Health Research/Cancer Research Network) to YSA, Manchester Experimental Cancer Medicine Centre Funding (HV and CW) and grants from the Wellcome Trust and a Royal Society-Wolfson award to ADS.

\section{Competing interests}

The authors declare that they have no competing interests.

Received: 20 August 2015 Accepted: 2 November 2015 Published online: 14 November 2015

\section{References}

1. Samalin E, Ychou M. Neoadjuvant treatment in upper gastrointestinal adenocarcinomas: new paradigms from old concepts? Curr Opin Oncol. 2007;19:384-9.

2. Bosetti C, Bertuccio P, Levi F, Lucchini F, Negri E, La Vecchia C. Cancer mortality in the European Union, 2008 1970-2003, with a joinpoint analysis. Ann Oncol. 2008;19:631-40.

3. Rachet B, Maringe C, Nur U, Quaresma M, Shah A, Woods LM, Ellis L, Walters S, Forman D, Steward J, Coleman MP. Population-basedcancer survival trends in England and Wales up to 2007: an assessment of the NHS cancer plan for England. Lancet Oncol. 2009;10:351-69.

4. Nosho K, Yoshida M, Yamamoto H, Taniguchi H, Adachi Y, Mikami M, Hinoda Y, Imai K. Association of Ets-related transcriptional factor E1AF expression with overexpression of matrix metalloproteinases, COX-2 and $\mathrm{iNOS}$ in the early stage of colorectal carcinogenesis. Carcinogenesis. 2005:26:892-9.

5. Tan YK, Fielding JW. Early diagnosis of early gastric cancer. Eur J Gastroenterol Hepatol. 2006;18:821-9.

6. Findlay M, Cunningham D, Norman A, Mansi J, Nicolson M, Hickish T, Nicolson V, Nash A, Sacks N, Ford H, Carter R, Hill A. A phase II study in advanced gastro-esophageal cancer using epirubicin and cisplatin in combination with continuous infusion 5-fluorouracil (ECF). Ann Oncol. 1994;5:609-16.

7. Mackay HJ, Mclnnes A, Paul J, Raby N, Lofts FJ, McDonald AC, Soukop M, Fullarton GM, Harris AL, Garcia-Vargas J, Evans TR. A phase II study of epirubicin, cisplatin and raltitrexed combination chemotherapy (ECT) in patients with advanced oesophageal and gastric adenocarcinoma. Ann Oncol. 2001;12:1407-10.

8. Tebbutt NC, Norman A, Cunningham D, Iveson T, Seymour M, Hickish T, Harper P, Maisey N, Mochlinski K, Prior Y, Hill M. A multicentre, randomised phase III trial comparing protracted venousinfusion (PVI) 5-fluorouracil (5-FU) with PVI 5-FU plus mitomycinCin patients with inoperable oesophago-gastric cancer. Ann Oncol. 2002;13:1568-75.

9. Cunningham D, Allum WH, Stenning SP, Thompson JN, Van de Velde CJ, Nicolson M, Scarffe JH, Lofts FJ, Falk SJ, Iveson TJ, Smith DB, Langley RE, Verma M, Weeden S, Chua YJ, Participants MT. Perioperative chemotherapy vssurgery alone for resectable gastroesophageal cancer. N Engl J Med. 2006:355:11-20.

10. Laoukili J, Stahl M, Medema RH. FoxM1: at the crossroads of ageingand cancer. Biochem Biophys Acta. 2007;1775:92-102.

11. Koo C-Y, Muir KW, Lam EW. FOXM1: from cancer initiation toprogression and treatment. Biochem Biophys Acta. 2012;1819:28-37.

12. Laoukili J, Kooistra MRH, Bras A, Kauw J, Kerkhoven RM, Morrison A, Clevers $\mathrm{H}$, Medema $\mathrm{RH}$. FoxM1 is required for execution of the mitotic programme and chromosome stability. Nat Cell Biol. 2005;17:126-36.

13. Major ML, Lepe R, Costa RH. Forkhead Box M1B transcriptionalactivity requires binding of $\mathrm{Cdk}$-Cyclin complexes forphosphorylationdependentrecruitment of p300/CBP coactivators. Mol Cell Biol. 2004;24:2649-61.

14. Fu Z, Malureanu L, Huang J, Wang W, Li H, van Deursen JM, Tindal DJ, Chen J. Plk1-dependent phosphorylation of FoxM1 regulates atranscriptionalprogramme required for mitotic progression. Nat Cell Biol. 2008;10:1076-82.

15. Dibb M, Han N, Choudhury J, Hayes S, Valentine H, West C, Ang YS, Sharrocks AD. The FOXM1-PLK1 axis is commonly upregulated in oesophageal adenocarcinoma. Br J Cancer. 2012;107:1766-75.

16. Hui MKC, Chan KW, Luk JM, Lee NP, Chung Y, Cheung LCM, Srivastava G, Tsao SW, Tang JC, Law S. Cytoplasmic forkhead Box M1 (FoxM1)in esophageal squamous cell carcinoma significantly correlates with pathological disease stage. World J Surg. 2012;36:90-7.

17. Strebhardt K, Ullrich A. Targeting polo-like kinase 1 for cancer therapy. Nat Rev Cancer. 2006;6:321-30.

18. Feng YB, Lin DC, Shi ZZ, Wang XC, Shen XM, Zhang Y, Du XL, Luo ML, Xu $X$, Han YL, Cai Y, Zhang ZQ, Zhan QM, Wang MR. Overexpression of PLK1 is associated with poor survival by inhibiting apoptosis via enhancement of survivin level in esophageal squamous cell carcinoma. Int J Cancer. 2009;124:578-88.

19. Zhao C, Gong L, Li W, Chen L. Overexpression of Plk1 promotes malignant progress in human esophageal squamous cell carcinoma. J Cancer Res Clin Oncol. 2010;136:9-16.

20. Raychaudhuri P, Park HJ. FoxM1: a master regulator of tumormetastasis. Cancer Res. 2011;71:4329-33.

21. Zhang N, Wei P, Gong A, Chiu WT, Lee HT, Colman H, Huang H, Xue J, Liu M, Wang Y, Sawaya R, Xie K, Yung WK, Medema RH, He X, Huang S. FoxM1 promotes b-catenin nuclear localization and controls Wnt target-gene expression and glioma tumorigenesis. Cancer Cell. 2011;20:427-42.

22. Weichert W, Ullrich A, Schmidt M, Gekeler V, Noske A, Niesporek S, Buckendahl AC, Dietel M, Denkert C. Expression patterns of polo-like kinase 1 in human gastric cancer. Cancer Sci. 2006;97(4):271-6.

23. Peters CJ, Rees JRE, Hardwick RH, Hardwick JS, Vowler SL, Ong CAJ, Zhang C, Save V, O'Donovan M, Rassl D, Alderson D, Caldas C, Fitzgerald RC. A 
4-gene signature predicts survival of patients with resected adenocarcinoma of the esophagus, junction, and gastric cardia. Gastroenterology. 2010;139(6):1995-2004

24. Lens SMA, Voest EE, Medema RH. Shared and separate functions of pololike kinases and aurora kinases in cancer. Nat Rev Cancer. 2010;10:825-41.

25. Li Q, Zhang N, Jia Z, Le X, Dai B, Wei D, Huang S, Tan D, Xie K. Critical role and regulation of transcription factor FoxM1 in human gastric cancer angiogenesis and progression. Cancer Res. 2009;69(8):3501-9.

26. Zeng J, Wang L, Li Q, Li W, Björkholm M, Jia J, Xu D. FoxM1 is up-regulated in gastric cancer and its inhibition leads to cellular senescence, partially dependent on p27 kip1. J Pathol. 2009;218(4):419-27.

27. Kanaji S, Saito H, Tsujitani S, Matsumoto S, Tatebe S, Kondo A, Ozaki M, Ito $\mathrm{H}$, Ikeguchi M. Expression of polo-like kinase 1 (PLK1) protein predicts the survival of patients with gastric carcinoma. Oncology. 2006;70(2):126-33.

28. Kim SM, Park Y-Y, Park ES, Cho JY, Izzo JG, Zhang D, Kim S-B, Lee JH, Bhutani MS, Swisher SG, Wu X, Coombes KR, Maru D, Wang KK, Buttar NS, Ajani JA, Lee J-S. Prognostic biomarkers for esophageal adenocarcinoma identified by analysis of tumor transcriptome. PLoS One. 2010;5(11):15074.

29. Dallas PB, Gottardo NG, Firth MJ, Beesley AH, Hoffmann K, Terry PA, Freitas $J R$, Boag JM, Cummings AJ, Kees UR. Gene expression levels assessed by oligonucleotide microarray analysis and quantitative real-time RT PCRhow well do they correlate? BMC Genom. 2005;6:59.
30. McInnes C, Wyatt MD. PLK1 as an oncology target: current status and future potential. Drug Discov Today. 2011;16(13-14):619-25.

31. Schöffski P, Blay JY, De Greve J, Brain E, Machiels JP, Soria JC, Sleijfer S, Wolter P, Ray-Coquard I, Fontaine C, Munzert G, Fritsch H, Hanft G, Aerts C, Rapion J, Allgeier A, Bogaerts J, Lacombe D. Multicentric parallel phase II trial of the polo-like kinase 1 inhibitor BI 2536 in patients with advanced head and neck cancer, breast cancer, ovarian cancer, soft tissue sarcoma and melanoma The first protocol of the European Organization for Research and Treatment of Cancer (EORTC) Network of Core Institutes (NOCl). Eur J Cancer. 2010;46(12):2206-15.

32. Olmos D, Barker D, Sharma R, Brunetto AT, Yap TA, Taegtmeyer AB, Barriuso J, Medani H, Degenhardt YY, Allred AJ, Smith DA, Murray SC, Lampkin TA, Dar MM, Wilson R, Bono JS, de Blagden SP. Phase study of GSK461364, a specific and competitive polo-like kinase 1 inhibitor, in patients with advanced solid malignancies. Clin Cancer Res. 2011;17(10):3420-30.

\section{Submit your next manuscript to BioMed Central and take full advantage of:}

- Convenient online submission

- Thorough peer review

- No space constraints or color figure charges

- Immediate publication on acceptance

- Inclusion in PubMed, CAS, Scopus and Google Scholar

- Research which is freely available for redistribution

Submit your manuscript at

www.biomedcentral.com/submit

() Biomed Central 